\title{
The old and the new Behavioral Economics: highlights of a trajectory
}

A velha e a nova Economia Comportamental: destaques de uma trajetória

\section{Igor Feitosa Lacôrte Ayroza}

igor.ayroza@gmail.com

Universidade Federal do Tocantins (UFTO)

\section{Helga Iwamoto}

helga.iwamoto@gmail.com

Universidade Federal do Tocantins (UFTO)

\section{Waldecy Rodrigues}

waldecy@terra.com.br

Universidade Federal do Tocantins (UFTO)

\begin{abstract}
In the present work, we sought to trace a trajectory with the elements considered essential in the constitution and consolidation of the Behavioral Economics as a theoretical and scientific field: starting from the old school to the formation of the so-called new school, however, with no ambition to exhaust the theme. The understanding of how the BE developed over the time will provide guidance to those interested in the topic to assimilate the context in which the BE came about, to learn about it's precursors, main concepts and research fields as well as provide indications of possible fields for the development of new research. Among the theoretical and scientific references are: Simon's bounded rationality, concepts of heuristics and biases, the two systems theory, the prospect theory, and the intertemporal choice.
\end{abstract}

Keywords: Behavioral Economics; Economic Psychology; Limited Rationality; Two Systems

Códigos JEL: D03; N01.

Resumo: No presente trabalho, buscou-se traçar uma trajetória com elementos considerados essenciais na constituição e consolidação da Economia Comportamental como campo teórico e científico: de sua velha escola até a formação da chamada nova escola, sem, no entanto, ambicionar o esgotamento do tema. Entende-se que a compreensão do percurso trilhado pela EC auxiliará e norteará o interessado na temática a assimilar o contexto em que a EC surgiu, conhecer seus precursores, principais conceitos e campos de pesquisa bem como fornecerá indícios de possíveis campos para o desenvolvimento de novas pesquisas. Dentre as contribuições, destacam-se: a o conceito de racionalidade limitada, os conceitos de heurísticas e vieses, a teoria dos dois sistemas, a teoria dos prospectos, bem como a teoria da escolha intertemporal.

Palavras-chave: Economia Comportamental; Psicologia Econômica; Racionalidade Limitada; Dois Sistemas

JEL Codes: D03; N01.

Recebido em: 22-02-2018. Aceito em: 18-05-2018. 


\section{INTRODUCTION}

Behavioral economics (BE) "emerged as a reaction to the deficiencies of the traditional economy" (HOSSEINI, 2003, p.393). According to Camerer (2015), the new discipline used knowledge from the areas of psychology and other social sciences to build its theoretical and experimental basis as an alternative to traditional economic theories based on the optimization of results. For the author, an important element in structuring the new discipline was the shift from a perspective based on mathematical logical calculations and utility maximizers to biologically plausible mechanisms. That is, in order to understand human behavior in the face of the economic field, we sought to leave aside the generative deductive models to favor the empirical models that consider the peculiarities of the context in which the individual is inserted. In this sense, Tomer (2007) considers that the scientific practice built by the behavioral economics distinguishes it from other economic schools.

Calhoun in his "Dictionary of the Social Sciences" defines behavioral economics as "a field concerned with the empirical validity of neoclassical premises about human behavior and where these premises are held to be invalid in relation to the more adequate description of behavior" (CALHOUN, 2002, p.38). Mullainathan and Thaler (2001, p. 1) define BE as "the combination of psychology and economics that investigates what happens in markets in which some agents exhibit human complications and limitations." As Samson (2014) states, BE "suggests that human decisions are strongly influenced by the context, including the way in which choices are presented" (SAMSON, 2014 p.44). For Bickel, Green, and Vulchinich (1995), behavioral economics is a relatively new theoretical and research area that engages in conducting experimental analyzes of human behavior.

According to Shiller (2005), BE brought benefits to the economic sciences even before being recognized as a discipline. Camerer (2015) points out that one of the most substantial contributions of behavioral economics to the economic field was the addition of boundaries to unlimited, computational abilities, willpower and selfishness present in the life of the rational economic agent. The basis for limiting these superhuman faculties comes mainly from psychology (CAMERER; LOEWENSTEIN, 2003), social sciences and more recently, from neuroscience.

Camerer (2015) considers that behavioral economics is useful mainly in contexts involving complex and difficult decisions to be reached. These decisions may relate to different contexts, namely, health, education, consumption, sustainability, etc. Angner and 


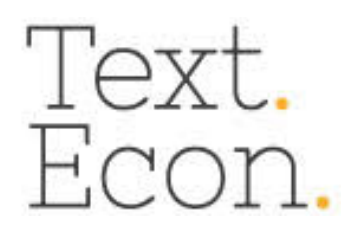

Loewenstein (2006) add to this list studies on the fields of neuroeconomics and affection and on states that adopt paternalistic government actions as well as those that opt for imperialist governmental actions. Some other authors add to this roll the design of public policies (LOW, 2011, SOMAN, 2015, THALER; SUNSTEIN, 2008).

In the present work, we will seek to trace a trajectory with the elements considered essential in the constitution and consolidation of Behavioral Economics as a theoretical and scientific field from its old school to the formation of the so-called new school; however, with no intention to exhaust the theme. The understanding of the path taken by the BE from its constitution to its consolidation will help and guide the interest in the theme to assimilate the context in which BE came about, to know its precursors, main concepts, and research fields, as well as provide indications of possible fields for the development of new research.

In this sense, the first topic in the article goes back to the historical antecedents of the Behavioral Economics. It will be seen where the first studies on the theme were carried out as well as who are the main authors related to the creation and development of BE as an area of knowledge and research. Theoretical elements of the considered "fathers" of BE, Katona, and Simon, will be addressed, emphasizing how their propositions influenced and impacted the new current of the economic thought. Next, we will see the expansion of BE studies to the present days, making the transition between the old and the new BE school. Finally, it will be approached fundamentals of the theory of Daniel Kahneman and Amos Tversky, influential researchers in the process of development and consolidation of $\mathrm{BE}$ as field of scientific studies in the economy area. Concerning the theme, the two theory of the systems, the prospect theory as well as the concepts of heuristics and biases and intertemporal choice will be approached.

\section{BE HISTORY BACKGROUNDS}

According to Hosseini (2003, 2011), in its current form, behavioral economics emerged between the 1950s and 1960s at two major US universities: Carnegie Institute of Technology (now Carnegie-Mellon University) and the University of Michigan. Those universities were the places where the founders of the new economic approach, namely Herbert Simon and George Katona, developed their studies largely in their careers. Sent (2004) points out that while the former was concerned with elements that influenced individual behavior in organizations, the latter was interested in issues related to consumer 


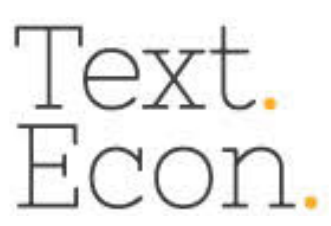

http://dx.doi.org/10.5007/2175-8085.2018v21n2p50

behavior and microeconomics problems. Initially, the new strand of the economy did not have a definite name. It was spoken in economic psychology or psychology economics. Only later did it become known as Behavioral Economics (HOSSEINI, 2011).

However, Sent (2004) argues that in addition to the two American universities, two other English institutes may also be considered as the cradle of behavioral economics: Oxford University and the University of Stirling. Whereas Oxford was keen to highlight the importance of case studies involving coordination and uncertainty in the economic sciences, Stirling emphasized eclecticism and the integration of economics with other disciplines. In common, the four different universities sought to refute the assumptions of the mainstream of economics whose primary focus was profit and utility maximization, with a view to developing alternatives to overcome these theoretical inconsistencies (SENT, 2004).

Accordingly, the publication of scientific papers on the field of behavioral economics has caused great admiration in its readers, who, faced with the findings of the new economic approach, began to criticize traditional economists, considering them unfit to make accurate forecasts of market trends (BICKEL ET AL, 1995). Angner and Lowenstein (2012) report that the first time the term was used in a scientific paper was in 1958 by Kenneth Boulgind and Harold Johnson. Although the two authors first used the term in a scientific publication, it is assumed that the term was coined by George Kantona (GILAD ET AL, 1984).

The tendency of behavioral economists to diverge from the traditional trend and its assumptions, namely: stable preferences, use of all available information for decision-making, and maximization of results (ZARRI, 2010) was perceived. This divergence led them towards biological approaches, which are molecular (traditionally from neurosciences) or evolutionary approaches (from the field of behavior analysis). Bickel et al. (1995) point out that the relationship between Economics and Biology has long been cited as Darwin pioneered the use of knowledge sharing in the areas by means of the influences of two important economists: Thomas Malthus and Adam Smith.

Behavioral economics can be divided into two phases: the old behavioral economics and the new behavioral economics (HOSSEINI, 2011; SENT, 2004). The oldest phase is marked by the works of George Katona and Herbert Simon (from the 1950s to 1970s). The new one includes the works of Daniel Kahneman, Amos Tversky, Richard Thaler and others (1970s to the present day). 
However, some say that the origin of behavioral economics predates World War II, and they hold the view that combined with the old phase of behavioral economics, it would be necessary to include the work of other researchers. Hosseini (2011) states that authors such as Erik Warneyd and Folke Olander, both Swedish, should be included in the BE pioneer list. In relation to the work of the Swedish authors, Hosseini (2011) emphasizes that the concept of economic psychology coined by them was highly discussed by the members of the Austrian school of economics in the early 1900s, therefore they are important for the process of building the history of BE. Another author, hardly remembered, is Gabriel Trade whose article La Psychologie Economique was published in 1902. In this paper, he defines economic psychology as "the study of the psychological bases in economic theory" (TRADE apud HOSEINE, 2011). Those are some of theorists prior to Kantona and Simon who, in general, are not quoted when the origin of behavioral economics is discussed.

Despite such considerations, the understanding of most authors is the same as those of Sent (2004). Thus, Angner and Loewenstein (2012) consider that the behavioral economics as it is understood nowadays, originates after World War II and had as one of its main motivations, the desire to develop a more realistic economic theory that could share knowledge from psychology.

For Hosseini (2003), although the supporters of the traditional economy sought to infer principles of the economic behavior of human nature to be generalized in all contexts, as well as in culture in general, Simon and Katona sought means to explain empirically (through experiments) how close or distant to actual human behavior were the behaviors prevailing in the economy mainstream. Next, the main contributions made by these authors for the development of $\mathrm{BE}$ will be elaborated.

\subsection{GEORGE KATONA AND ECONOMIC PSYCHOLOGY}

According to Hosseini (2011), the theory of Katona was influenced by the problemsolving attributes of Gestalt Psychology in addition to his great interest in issues related to public policies. His initiative to insert theoretical and empirical elements of psychology into economic theory had as its objective to make the economic analyzes more realistic, making them more relevant for the use in public policies. Katona realized that traditional economic theory based its theoretical models on abstractions of reality without the concern of testing 


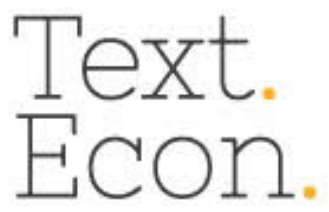

them empirically. Hence, many of these theories did not portray the reality; moreover, its use in public policies had often unexpected consequences.

Although little publicized and low regarded, the work developed by George Katona (1901-1981) is considered by some authors (HOSSEINI, 2011, LIKERT, 1972, STRUMPEL ET AL, 1972, GILAD ET AL 1984) as pioneer in the field of BE. Not only did Herbert Simon started a new field of research, but Katona also played a vital role in consolidating the new economic discipline as an alternative to the ideals of neoclassical economics.

Likert (1972) in Courageous Pioneer: Creating a New Field of Knowledge points out that Katona introduced "the development of a new body of knowledge by integrating the gap between economics and psychology. This field of work is generally called economic psychology or behavioral economics" (LIKERT, 1972, p.33). Hosseini (2011) considers that the economists has little knowledge and poorly use the contributions of George Katona having little influence on the traditional theorists. For the author, Katona was misunderstood by many economists in his attempt to create an economy based on the assumptions of psychology.

Katona criticized the absence of psychological basis in the economic sciences because he considered that the discipline of psychology could provide important contributions to the field of economics, such as "discover and analyze the forces behind economic process, the forces responsible for economic actions, decisions and choices" (HOSSEINI, 2011, p.979). In this sense, he sought to describe a psychological approach to economic analysis and studies on the field of economic behavior. In addition to Psychology, he was also influenced by Sociology and other non-normative behavioral sciences. To obtain the target information, he generally "used surveys and interviews to learn about attitudes, aspirations, expectations, optimism/pessimism, social learning/cognition, habits and stereotypes" presented by individuals in different contexts (TOMER, 2007, p. 470).

According to Curtin (1984), Katona's work highlights three essential reasons for the interaction between psychology and economics. The first is that behavioral economics is concerned with behaviors related to decisions made by involving economic issues in their different forms, whether in the role of consumer, worker or employer. For the author, the analysis of behavior in different situations requires integration between the psychological antecedents of economic behavior, namely, motives, attitudes and expectations (CURTIN 1984, 496). Regardless of the nomenclature adopted by the new field of research, it was intended that this field would be interdisciplinary and directed towards the understanding of 


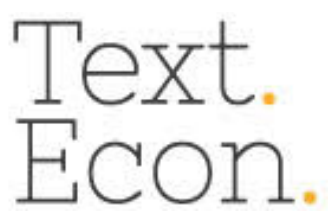

human behavior. The second reason pointed out by Curtin (1984) is that instead of focusing on the economic consequences of human behavior, behavioral economics sought to understand the elements present in the decision-making process. Finally, the third reason is about the empirical character of behavioral economics. Instead of basing its theoretical construction on deductive elements, the novel discipline sought to empirically prove its assumptions.

According to Katona:

The consumer is a human being influenced by his or her experience. Their sociocultural norms, attitudes and habits, as well as their belonging to groups, all influence their decisions. He is apt to prefer shortcuts, to follow golden rules and to follow a behavioral routine. But he is also capable of acting intelligently. When he feels that a subject really matters, he will deliberate and choose the best of his ability (KATONA, 1975, p.218).

This statement by Katona goes against the assumptions of neoclassical theory that states that consumer preferences are stable and that the environment has no influence on the choices made. However, it agrees with Simon's theory (1955) on the use of heuristics as guiding principles of decision making, which can either help or hinder the results of individuals' choices.

In relation to the elements common to the theories of Katona and Simon, Sent (2004) emphasizes their positions divergent to the presuppositions of neoclassical economics. Among them, the use of the utility function to determine the preferences of individuals. The authors disagree that people's preference can be given by a mathematical function and prefer to draw such preferences through experiments and empirical research in order to describe a certain behavior more accurately.

Another convergent point between the two authors highlighted by Sent (2004) is the contestation of the concepts of rationality and maximization of utility proposed by the neoclassical theory. The authors understand that people are not always able to make the best decisions because of the shortcuts (KATONA, 1975) or heuristics (SIMON, 1955) that they adopt in the decision-making process, thus showing that their rationality is not so unlimited as it is diffused by neoclassical theorists.

\subsection{SIMON AND THE BOUNDED RATIONALITY}




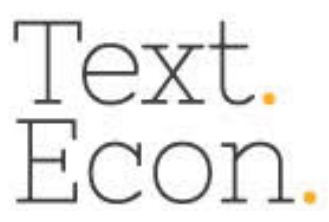

http://dx.doi.org/10.5007/2175-8085.2018v21n2p50

In 1955, Simon wrote an article entitled The Behavioral Model of Rational Choice whose objective was to develop an alternative to the understanding of neoclassical economics about (unlimited) rationality as the main element for decision making. For him, the theory about the economic man, able to calculate and choose precisely the alternatives that are most beneficial to optimizing his earnings is not the best basis for the decision-making process. In this work, Simon (1955) attempted to structure a theory of behavior, both within individual decisions and in the context of group decisions, in the organizational context. He concluded that many discrepancies in the organizations could be solved by replacing the paradigm of the unrestricted efficiency of the homo economicus by the notion of the administrative man (SIMON, 1964), fallible, who makes decisions based on scarce and not always reliable information.

This publication was an important step towards the development of the concept of bounded rationality proposed by Simon in 1957, which, according to Hosseini (2011) was a preponderant factor for the emergence of the field of behavioral economics. For Melo and Fucidji, "the argument of bounded rationality (...) was constructed from the premise of the dynamics of the economic system, in which not only the actions of agents change over time, but also the environment in which they act." (MELO, FUCIDJI, 2016, p.623). That is, Simon considered that conditions are not always conducive to decision-maximizing results and the impossibility of predicting future environmental conditions. Thus, Simon (1957) proposed an alternative to the concept of rationality advocated by the neoclassical economic current.

Barros (2010) states that the term "bounded rationality" was first used in 1957 in the book "Models of Man, Social and Rational". Schwartz (2002) reports that in his studies, Simon realized that, when making certain decisions, people did not get the information they needed to figure out the best paths to follow neither were they able to assess the relevant information to achieve the desired goals. In this work, Simon, when discussing the concept, states that:

(...) the ability of the human mind to formulate and solve complex problems is very small compared to the size of the problems whose solution is required by an objectively rational behavior in the real world or even a reasonable approximation to such objective rationality (SIMON, 1957, p 198). 


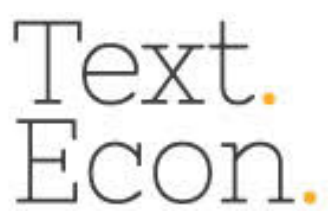

http://dx.doi.org/10.5007/2175-8085.2018v21n2p50

Barros (2010) and Sbicca (2014) understand that the concept of bounded rationality proposed by Simon is a concept constructed in a negative way since it is structured in denying the rationality proposed by the neoclassicals. In the same way, Schwartz (2002) understands that Simon elaborated the concept of bounded rationality to expose the inadequacy of the concept of rationality proposed by the traditional economists.

Bounded rationality refers to another important concept in Simon's theory of satisficing (SCHWARTZ, 2002). This concept refers to a form of rationality that:

(...) considers the knowledge about the real behavior of human choice, assuming that the decision maker should seek alternatives compatible with a remarkably incomplete and imprecise knowledge about the consequences of actions and choices that are expected as objectives to be achieved satisfactorily (SIMON, 1997, p. 17).

This search for satisfactory solutions leads to a condition of uncertainty given the scarcity of available knowledge to support decision-making. According to Dosi and Egidi (1991, p.145), "uncertainty in human behavior derives from the incompleteness of the knowledge necessary to predict future events, to undertake any course of action and to control its results".

By considering that the realization of the best choice is something almost impossible to be discovered and identified, Earl (2016) considers satisficing as a matter of survival in certain settings and that the decision-maker simply needs to find solutions that are satisfactory and sufficient to meet their needs.

Similar to Katona, in his work "Psychological Foundations of Economic Behavior" published in 1951, Simon, in "Theories of Decision-making in Economics and Behavioral Science" sought to reflect on the influence of psychology on economics and the opposite influence of economics on psychology (SIMON, 1959). He considered that the interchange between the disciplines was a tendency and the interrelationship between them would help in the understanding of situations related to the adaptation to different types of environment such as: the decision making in contexts in which the individual is alone and calm, or in turbulent situations involving many people. Despite the great effort to understand how the individual makes decisions, Simon proposed to understand the role of social influence in organizations in the decision-making process of the individual (TOMER, 2007). 


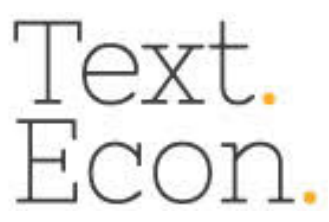

http://dx.doi.org/10.5007/2175-8085.2018v21n2p50

For his pioneering research involving decision-making processes in economic organizations, Simon was awarded the Nobel Prize for economics in 1978. In his opening words during the award ceremony, he restated that he considered economics a psychological science (SIMON, 1978).

Simon $(1959,1978)$ disapproved the lack of scientific methods and empirical evidence of neoclassical economic theory by claiming that it required the description of the human decision-making processes in situations involving a greater degree of complexity. In this sense, he emphasized the role of behavioral theory in the decision-making process (anchored in an extensive mass of descriptive data collected both in the laboratory and in the field) as a support for people to solve their problems (SIMON, 1978).

Following Simon, other researchers contributed even more to the consolidation of BE as an alternative to the traditional economic model. These contributions will be presented below.

\section{DEVELOPMENT OF THE FIELD OF THE BEHAVIORAL ECONOMICS}

Heukelom (2014) states that during the 1990s and 2000s, the work of some researchers was important for the development of behavioral economics. According to author Kahneman, Tversky, Thaler among others:

(...) were responsible for the expansion of what was once only a small research program focused on the inconsistencies of neoclassical economic theory in the field of financial economics in a dominant research program concerned with seeking alternatives beyond behavioral decision research in various scientific disciplines to define behavioral economics more explicitly in opposition to neighboring fields such as experimental economics and psychology (HEUKELOM, 2014, p. 171).

The objective of the new field of research was to develop and to consolidate its identity independently of the other fields that shared some assumptions with it so to earn notoriety and respect of the academic community. This development contributed to the consolidation, expansion and transformation of the behavioral economics into a broad and stable economic research program. In order to do so, it was necessary to question and confront the already established theoretical presuppositions of the economic mainstream. 
Tversky and Kahneman (1974) consider that the actions, decisions and behaviors expressed in the real world do not fit the way of acting and thinking of conventional or neoclassical economics. For them, there are inconsistencies in the classical assumptions that do not find empirical support in the real world, and the neoclassical theorists should pay more attention to the construction and elaboration of theoretical formulations on human behavior. Thaler and Sunstein (2008) agree with the positioning of Kahneman and Tversky and highlight the efforts of $\mathrm{BE}$ researchers to try to recreate and guide the assumptions of economic science on the basis of behavioral science.

Kahneman and Tversky (1972) understand that conventional/neoclassical economic theory can play a normative or descriptive role. The discussion of this division is a recurring theme in the field of economic sciences (HEUKELOM, 2014). The normative part is related to the number of rules that govern rational decision making, such as expected utility theory, stability of preferences and the dissociation of social influence from individual preferences (LOW, 2011). Considering those rules as a sieve, economists judge whether a particular action is correct or incorrect. However, the descriptive character of the theory refers to the description of real human decision making that, as a rule, is predictably and systematically diverted in comparison to its normativity. For Thaler (1980), the neoclassical economic theory is responsible for the main assumptions that influence the referrals in these two aspects of economic theory.

Given these characteristics of economic theory, normativity and descriptiveness, Thaler (1980) criticizes the way in which they are used. In his opinion, although conventional (especially neoclassical) economists argue that economic theory should be based on normativity, determining how rational people should be in their decisions, and also in descriptiveness, predicting how people actually behave, this form of thinking and acting leads these economists to make systematic errors in describing and predicting people's choices. He makes it clear his disagreement when he says that "in well-defined situations, individuals act inconsistently with economic theory" (THALER, 1980, p. 39).

The distinction of Kahneman and Tversky on the normative and descriptive characteristics of neoclassical economic theory served as a methodological basis for behavioral economists to develop a new look on the subject (HEUKELOM, 2014). In behavioral research, both laboratory and field experiments are performed and the observed behaviors are compared to the traditional decision theory, which is used as a parameter for 


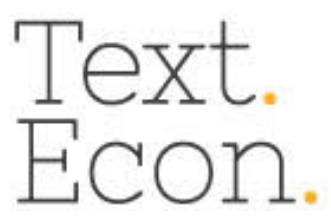

evaluating the results. Thus, considering that individuals act according to normative rules, researchers try to understand under what conditions individuals make mistakes or act in disagreement with what is theoretically regulated (HEUKELOM, 2014).

Kahneman and Tversky have played a key role in the development of a study in the field of EC. Among the main contributions of the authors, can be highlighted the study of human cognition and its failures as well as the prospects theory, seen in the sequence can be highlighted.

\subsection{KAHNEMAN AND TVERSKY: TWO SYSTEMS, HEURISTICS AND BIASES AND THE PROSPECTS THEORY.}

\subsubsection{Two systems}

Kahneman and Tversky adopted the concept of two systems of psychologists Keith Stanovich and Richard West (KAHNEMAN, 2012). Originally, the authors intended to explain why people's judgments and decisions generally do not fit the formal perspective of rationality (SAMSON, 2014). Conventionally, these systems are called system 1 (s1) and system 2 (s2). According to Kahneman (2012, p.26), system 1 "operates automatically and rapidly, with little or no effort and no perception of voluntary control" while system 2 "allocates attention to laborious mental activities that require it, including complex calculations (...) often associated with the subjective experience of activity, choice and concentration". Samson (2014) complements the concept by saying that s2 monitors mental operations and manifest behavior, but they are not always successful in their assignments.

Kahneman (2012) basically works with three possible interactions between systems. The first one, s1 accumulates the impressions and feelings that will serve as the basis for the consolidations of beliefs that will subsidize the choices that will be made by s2. The second possibility stems from the ability to generate patterns of complex thoughts that will be worked slowly and systematically in the orderly construction of thoughts. Finally, s2 is responsible for containing the impulses and sudden associations of s1, avoiding compulsive actions.

There are cognitive processes that are jointly controlled. This is the case of attention, controlled by both systems. In the case of $s 2$, it requires some effort to sustain its focus. If there are distractions, the attention is diverted, thus remaining under the tutelage of $\mathrm{s} 1$ (KAHNEMAN, 2012). It is possible to intervene and change s1 by continually maintaining 


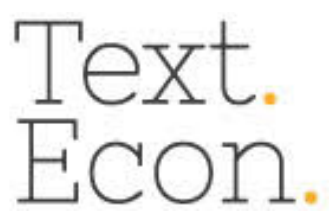

focus on the action or behavior that one wants to change: the persistence of focus affects autonomous functions of human cognition, controlled by s1, such as attention and memory.

In short, whenever we are awake, both systems operate uninterruptedly. The s2 is in stand by mode, running slowly, idly, waiting to be triggered. On the other hand, s1 is always in motion, provoking s2 continuously. When s2 accepts a certain provocation from s1, Kahneman $(2012,29)$ states that "impressions and intuitions become beliefs, and impulses become voluntary actions." In this case, there is the process of converting a simple impulse into deliberate actions or attitudes. When there is no novelty and the systems follow their flows normally, s2 is practically unaffected by the requests of $\mathrm{s} 1$.

To illustrate how the two systems work, Kahneman (2012), in his book "Thinking, Fast and Slow" discriminates different actions that we carry out in our daily life, inherent in each of the systems, as it can be seen in the table below.

Table 1 - Examples of actions performed by the two systems

\begin{tabular}{|c|c|}
\hline System 1 & System 2 \\
\hline $\begin{array}{l}\text { Detects that one object is more distant than } \\
\text { the other }\end{array}$ & Focuses on circus clowns \\
\hline $\begin{array}{l}\text { Focuses on the source of sudden loud } \\
\text { sounds }\end{array}$ & Finds a woman with white hair \\
\hline $\begin{array}{l}\text { Makes a "face of disgust" when seeing a } \\
\text { horrible photo }\end{array}$ & $\begin{array}{l}\text { Probes the memory to identify an amazing } \\
\text { sound }\end{array}$ \\
\hline Understands simple sentences & Tells someone his or her phone number \\
\hline Detects hostility in a voice & $\begin{array}{l}\text { Checks the validity of a complex logical } \\
\text { argument }\end{array}$ \\
\hline
\end{tabular}

Source: Kahneman (2012), adapted by the author.

Kahneman (2012) has shown that while actions related to s1 are linked to the knowledge stored in the memory and are fast and easy to access, actions related to s2 require focus and attention. As a rule, they are interrupted when distractions occur, diverting attention.

The perception of some phenomena can be influenced by cognitive mechanisms that shorten the decision-making process so that people do not waste too much time processing information. These mechanisms are known as heuristics and are usually commanded by s1. Heuristics contribute to the bias of the perception of facts, or in other words, they use 


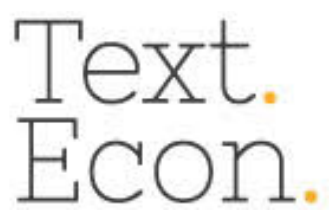

http://dx.doi.org/10.5007/2175-8085.2018v21n2p50

prejudices that affect the inputs of information and change the way the individual will process them and, therefore, the options that will be chosen.

\subsubsection{Heuristics and biases}

According to Heukelom (2014), the term heuristic in the BE context arose in the early 1970s. Although it was Simon who first used it, there is no evidence that Kahneman and Tversky based their concept on Simon's studies. Simon defined heuristics as: "any principle or device that contributes to the reduction of the average search time for a solution" (NEWELL; SIMON, 1962, p. 182 apud SCHWARTZ, 2002). Tversky and Kahneman (1974), in "Judgment under Uncertainty: Heuristics and Biases", argue that people rely on a limited number of heuristic principles that reduce the tasks of evaluating probabilities and predictive values in order to simplify the operations of judgment. In other words, heuristics and biases are like cognitive shortcuts that the agent accesses in the decision-making process. They are often quite useful, but sometimes lead to systematic errors (TVERSKY; KAHNEMAN, 1982, p.3). In this sense, Gigerenzer and Gaissmaier (2011) state that heuristics have functional character and cannot be considered authentic copies of the world, the reason why they can both lead to satisfactory or unsatisfactory results.

Heukelom (2014) considers that the two definitions refer to different paths. The author ponders that Simon's use of the term refers to the use of rules of thumb to make decisions. These rules serve to "improve the decisions made given the constraints that the individual faces in terms of information, cognitive ability and time" (HEUKELOM, 2014, p. 117). Whether heuristics yield positive results, they are maintained; otherwise, they are discarded. In Tversky and Kahneman's theory "the function of heuristics is to simplify and to reorganize the decision of a problem" (HEUKELOM, 2014, p.117). The objective of heuristics is to try to obtain the best results given the conditions and the context of the decision making.

The fundamental difference between the two conceptions is that, in Simon's theory, heuristics function as mechanisms for producing and guiding decisions based on experiences previously experienced. In Tversky and Kahneman, they serve to reorganize the input of information considering the likely paths to be followed in the decision-making process. More specifically, in the first, heuristics serve as rules to guide decision making and in the second, as elements that will influence the received information and that will be used in the decisionmaking process. Another point of divergence is that while for Simon the heuristics can be 


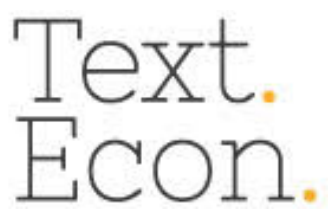

http://dx.doi.org/10.5007/2175-8085.2018v21n2p50

adapted to the present situation of the individual, in Tversky and Kahneman, there is no such possibility of adaptation, that is, the individual heuristics do not change (HEUKELOM, 2014).

Tversky and Kahneman (1974) highlight three main heuristics generally present in situations involving uncertainty: representativeness, availability and anchoring. Heukelom (2014) adds that although the authors have devoted themselves only to these heuristics, considering them the most important, if one considers the complexity of the human mind, there is no way to determine the exact number of heuristics that exist.

Representativeness can be described as an increased belief in a higher probability of obtaining a particular response from a given event by virtue of a successive coincidence in obtaining such responses (TVERSKY; KAHNEMAN, 1974). The recurrence of the same response becomes representative, although it does not mean that it will persist ad infinitum. In a game of dice, where the first four moves resulted in number three, through the representativeness heuristic, an observer who followed the whole development of the game may consider that the result of the fifth move will inevitably also be three.

Regarding availability, it usually occurs in circumstances involving assessments of risky situations, where people tend to overestimate a fact by the frequency that this event is evoked by memory (SBICCA, 2010). Judgments are made based on the ease with which an event emerges mentally (TVERSKY; KAHNEMAN, 1974) linking acquired information to existing information (HEUKELOM, 2014, p.117). As an example, consider parents who plan their children's vacation on the coast and see on the news that there has been a shark attack on a particular beach resulting in the death of a bather. Then, as they pass by a newsstand, they realize that the fact has gained the initial page of the main newspapers of the region where they live. Through the availability heuristic, the image of the pictures in the newspapers and images of television news easily emerge in the memory. The parents concerned about their children's well-being tend to cancel the beach vacation for fear that their children will be attacked by sharks (without considering that the beach they planned to go is far from the usual shark route).

Finally, anchoring refers to the linking of prior information to a fact that had taken place, as a basis for a judgment or decision-making. In general, it occurs unconsciously; it is generated by an initial event that will serve as a reference for later judgments (TVERSKY; KAHNEMAN, 1974). Consider a male who seeks a loving relationship and has a younger 


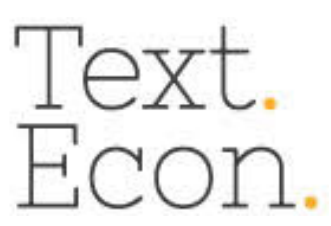

http://dx.doi.org/10.5007/2175-8085.2018v21n2p50

sister whom he considers immature. Through the anchorring heuristic, this person tends to consider that other women of the same age range of his sister are also immature excluding them from their invested. Thus, the "mature" brother anchors his perception in his experience with his sister and generalizes similar situations. Having a younger sister who considers immature does not mean that women of the same age group are all immature.

Kahneman and Tversky (1979) consider that people rely on heuristics to make decisions, especially in situations where they are undecided and the likely outcomes of these decisions are uncertain. These decisions, as it can be seen, may lead to systematic errors or sound decisions. In addition to the heuristics, another important aspect that affects the decision-making process worked out by Kahneman and Tversky is the prospect theory. This theory seeks to understand people's willingness to take risks in face of particular decisions and it will be treated next.

\subsubsection{Prospect theory}

Another important work by Kahneman and Tversky is "Prospect Theory: An Analysis of Decision Under Risk" published in 1979. In an attempt to undermine the conceptions of human nature proposed by the mainstream of neoclassical economics (SANSOM, 2014), the authors criticized the expected utility theory, and their rationality as decision-making models under risk. To counter this model, Kahneman and Tversky (1979) develop an alternative model called "The Prospect Theory". Heukelom (2014) considers this work as the first attempt to produce a complete theory of human decision-making in the face of uncertainty.

The basic assumption of prospect theory is that the certainty effect contributes to risk aversion in choices that involve certain gains and a propensity to risk, in choices that involve certain losses (KAHNEMAN; TVERSKY, 1979, KAHNEMAN, 2012; SBICCA 2010). Samson (2014, p.2) adds: "predisposition to take risks is influenced by the way choices are framed."

The prevailing theory was Daniel Bernoulli's expected utility theory of 1738, which gained greater prominence with von Neumann and Morgenstern in 1944. According to Heukelom $(2014,38)$, Bernoulli's theory argued that:

(...) individuals base their choices on two or more outcomes not on the monetary or objective value of the results, but on their subjective individual assessment of these results (...) and labeled this individual 


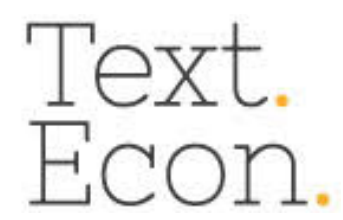

valuation to be "moral value" and supposing that its expansion diminishes with the increase of the monetary results.

The figure below shows the variables that influence expected utility from Bernoulli's point of view.

Figure 1 - Relationship between monetary value (horizontal axis) and moral value (vertical axis based on Bernoulli's works)

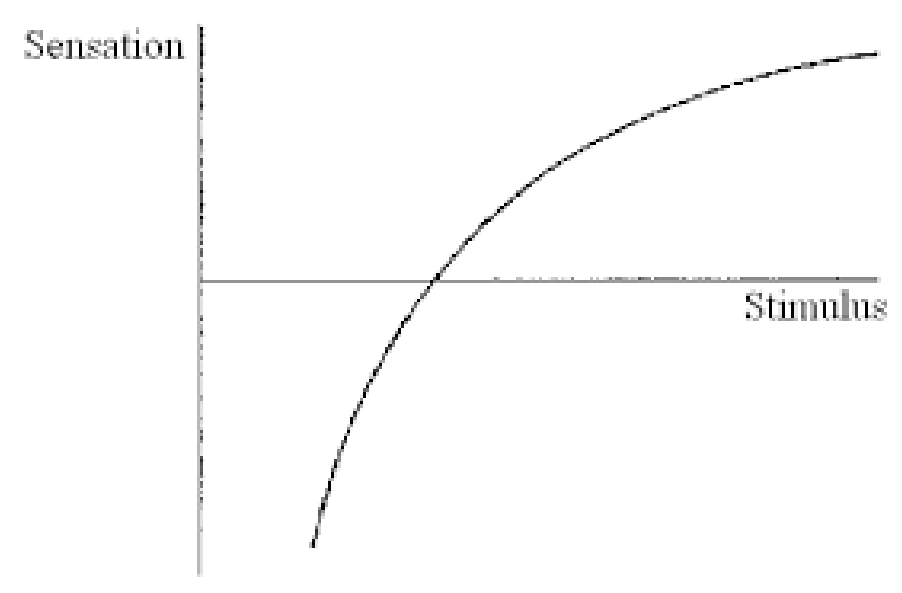

Source: Heukelom (2014).

Bernoulli's theory considers only the variable "monetary value" to determine the expected utility. In this sense, Kahneman (2012) states that it is necessary to know in addition to the "monetary value", in which point of reference, the gains and losses that are evaluated are based. The author has shown that people generally think in terms of expectation of relative utility in relation to a certain point and not in terms of absolute utility as advocated by Bernoulli (KAHNEMAN, 2012). The theory indicates that people are averse to loss and this aversion is greater than in relation to equivalent gains; people are more likely not to take risks in order to avoid probable losses as shown in the figure below.

Figure 2 - Psychological value of gains and loss aversion 


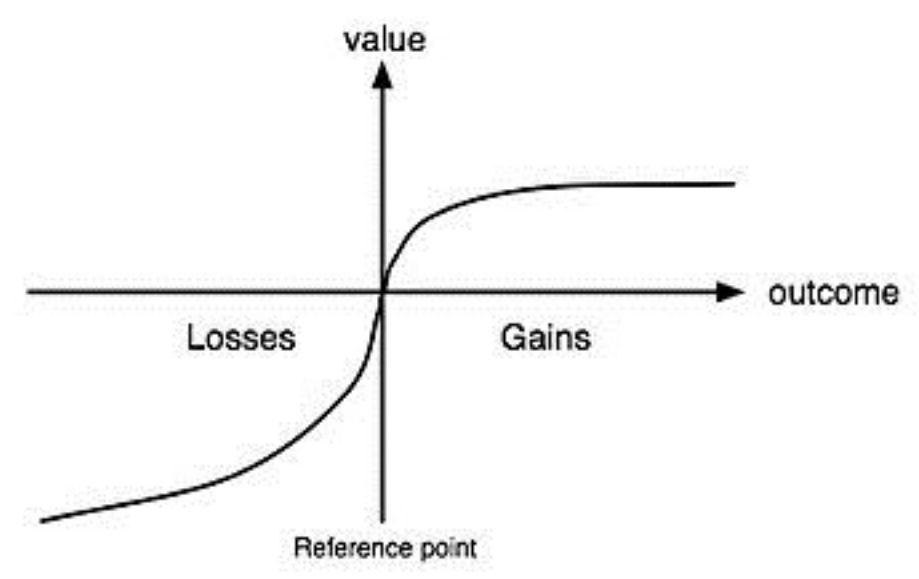

Source: Kahneman (2012)

Looking at the figure, a division between two distinct parts can be seen: one on the left side and another on the right side and separated by a neutral reference point (which Bernoulli's theory does not have). While Bernoulli regards monetary values as value carriers, Kahneman considers "the psychological value of gains and losses as value holders in prospect theory." (KAHNEMAN, 2012, p.301). The asymmetry of the "S" curves shown in the graph displays a considerable difference in slope from the curve reference point (KAHNEMAN, 2012; JUST, 2014) and the changes occurring at the reference point, revealing that the reaction of the individuals is stronger in relation to losses than in the reaction to the corresponding gains.

To sum up, Kahneman (2012) states that the graph represents aversion to the losses that the individuals face in certain situations of choice, and to avoid them, they are willing to take greater risks. Just (2014) considers that the prospect theory satisfies satisfactorily the decisions made under risk in experiments observed in laboratories and, when applied in the field, it can be recognized in many observed behaviors.

The fact that people are constantly confronted with choices, even if they evoke the sense of aversion to taking risks, there may be consequences that vary, in a timely fashion, depending on when the decision is made. By choosing to accomplish a task now may result in different consequences from choosing to accomplish the same task in the future. And this is another important field explored by BE, the intertemporal choices. 


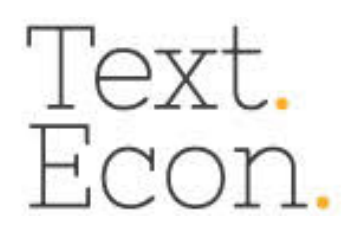

http://dx.doi.org/10.5007/2175-8085.2018v21n2p50

\subsection{INTERTEMPORAL CHOICE}

According to Heukelom (2014), behavioral economists started their studies in the field of intertemporal choices in the early 1990s. Some of the consequences of these studies contributed to the development of the two systems approach, seen earlier. These two assumptions were chronologically the first major themes in studies on the field of behavioral economics and these days, they still remain relevant (HEUKELOM, 2014).

Camerer et al. (2003, p. 162) consider intertemporal choice as "decisions involving exchanges between costs and benefits occurring at different times". In the same sense, Samson (2014) defines intertemporal choice as:

Field of research concerned with the relative values that people assign to the rewards at different time points. In general, research indicates that people are biased towards the present and tend to discount the rewards of the future (SAMSON, 2014, p.20).

In general, according to the theory of intertemporal choice, individuals tend to prefer gains in the present more than in the future, leaving aside concerns about how they will be in the future in the face of the same task, action or experience. In this sense, Soman (2015) reports that empirical research has shown that consumers are short-sighted (they evaluate the present results disproportionately in relation to the future) and are inconsistent (their choices change when they approach one of the options).

Walter Mischel made an important experiment in the field of intertemporal choice in the late 1960s (SOMAN, 2015). In this study, a marshmallow on a plate was offered to some children, but they were told that if they could wait for fifteen minutes without eating it, they could get a second marshmallow. At the end of the research, Mischel et al. (1989) presented evidence showing that children who were able to postpone gratification had better results in their lives: better satisfactory indices and educational achievements, better body mass indexes, among others.

\section{FINAL CONSIDERATIONS}

Behavioral economics, although it is a new area of knowledge, has shown great potential for development as far as the scientific evidence of economic assumptions is concerned. As seen from his old school with Katona and Simon, there was the search and commitment to prove and validate the premises defended by the traditional economic school in order to bring greater credibility and reliability to the economic field. After the pioneers of 


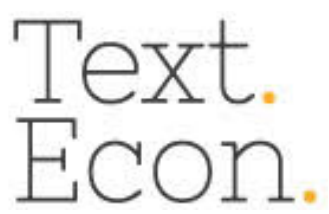

http://dx.doi.org/10.5007/2175-8085.2018v21n2p50

the old school, other important researchers, belonging to the so-called new school of behavioral economics, followed with the theoretical and mainly scientific development of the discipline, among them Tversky and Kahneman.

Among the theoretical and scientific contributions of the BE some important concepts were seen, such as the bounded rationality proposed by Simon, the concepts of heuristics and biases proposed by Tversky and Kahneman and their distinctions with the concepts proposed by Simon, as well as the two systems theory, prospect theory of Tversky and Kahneman, and by intertemporal choice theory.

It is worth noting that the aim of the present study is far from the exhaustion of the theme. There was only one attempt to trace a cohesive trajectory, choosing some of the many important facts that have occurred since the constitution of the Behavioral Economics as an area of knowledge, until its consolidation as a fertile field of scientific research.

\section{REFERENCES}

ANGNER, E.; LOEWENSTEIN, G. Behavioral Economics, working paper, Carnegie Mellon, to appear in Elsevier's Handbook of the Philosophy of Science, v. 5, 2006. Disponível em $<$ https://www.cmu.edu/dietrich/sds/docs/loewenstein/BehavioralEconomics.pdf $>$. Acesso em 25 ago. 2015. 2006.

ANGNER, E.; LOEWENSTEIN, G. Behavioral Economics. In: Maki, U. (Ed.). Handbook of the Philosophy of Science. Amsterdam: Elsevier, v. 13, 2012. p. 641 - 689.

BARROS, G. Herbert A. Simon and the concept of rationality: Boundaries and procedures. Brazilian Journal of Political Economy, São Paulo, v. 30, nº 3, p 455-472, jul./set. 2010.

BICKEL, W.; GREEN, L.; VUCHINICH, R. Behavioral Economics (Editorial). Journal of the experimental analysis of behavior, v. 64, $\mathrm{n}^{\circ} 3$, p. 257-262, nov. 1995.

CALHOUN, C. Dictionary of the social sciences. Oxford: Oxford University Press, 2002.

CAMERER, C.; LOEWENSTEIN, G. Behavioral economics: past, present, future. In: Camerer, C., Loewenstein, G., Rabin, M. Advances in Behavioral Economics. Princeton: Princeton University Press, 2003. p. 3 - 51.

CAMERER, C. et al. Advances in Behavioral Economics. Princeton: Princeton University Press, 2003. 


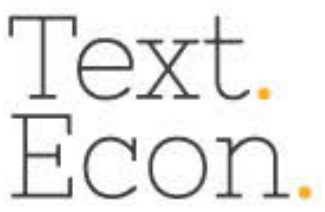

http://dx.doi.org/10.5007/2175-8085.2018v21n2p50

CAMERER, C. Behavioral Economics. Current Biology, v. 24, nº 18, p. 867-871, set. 2015.

CURTIN, R. Curtin on Katona. In: Speigel, H.; Samules, W. Contemporary Economics in Perspective. Greenwich, Connecticut/London: JAI Press Inc., 1984, p. 495-522.

DOSI, G.; EGIDI, M. Substantive and procedural uncertainty: an exploration of economic behaviors in Changing Environments. Evolutionary Economics, v. 1, n 2, p. 145-168, jun. 1991.

EARL, P. The Evolution of Behavioral Economics. In Frantz, R. Handbook of Behavioral Economics. Routledge, 2016.

GIGERENZER, G; GAISSMAIER, W. Heuristic Decision Making. Annual. Review of. Psychology, v. 62, p 451-82, jan. 2011.

GILAD, B.; KAISH, S.; LOEB, P. From economic behavior to behavioral economics: The behavioral uprising in economics. Journal of Behavioral Economics, vol 13, no 2, p. 1-24, dez./mar. 1984.

HEUKELOM, F. Behavioral Economics: A History. Nova York: Cambridge University Press, 2014.

HOSSEINI, H. The arrival of behavioral economics: from Michigan, or the Carnegie School in the 1950s and the early 1960s. Journal of Socio-Economics, v.32, n ${ }^{\text {o }}$, p. 391-409, set. 2003.

HOSSEINI, H. George Katona: A founding father of old behavioral economics. The Journal of Socio-Economics, v. 40, nº 6, p. 977-984, dez. 2011.

JUST, D. Introduction to behavioral economics: noneconomic factors that shape economic decisions. Nova Jersey: Wiley Press, 2014.

KAHNEMAN, D.; TVERSKY, A. Subjective Probability: A Judgment of Representativeness. Cognitive Psychology, v. 3, n 3, p. 430-454, jul. 1972.

KAHNEMAN, D.; TVERSKY, A. Prospect Theory: An Analysis of Decision under Risk. Econométrica, v. 47, n 2, p. 313-327, mar. 1979.

KAHNEMAN, D. Thinking, fast and slow. Translation: Cássio de Arantes Leite. - Rio de Janeiro: Objetiva, 2012.

KATONA, G. Psychological Economics. London: Elsevier, 1975.

LIKERT, R. Courageous pioneers: creating a new field of knowledge. In: Strumpel, B., Morgan, J.M., Zahn, E. (Eds.), Human Behavior, in Economic Affairs. San Francisco: JessayBass Inc., 1972, p. 4-6. 


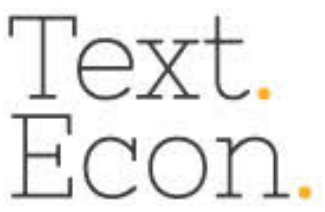

http://dx.doi.org/10.5007/2175-8085.2018v21n2p50

LOW, D. Cognition, Choice and Policy Design: In Low, D. (Org.) Behavioral Economics and Policy Design. Singapore: World Scientific Publishing Company; 2011.

MELO, T. M.; FUCIDJI, J. R. Bounded rationality and decision-making in complex systems. Revista de Economia Política, vol. 36, nº 3, p. 622-645, jul.-set. 2016.

MISCHEL, W, et al. Delay of gratification in children. Science, v. 26, n 244, p. 933-938, jun. 1989.

MULLAINATHAN, S.; THALER, R. Behavioral economics, 2001. Disponível em: $<$ http://www.nber.org/papers/w7948.pdf $>$. Acesso em: 15 nov. 2015.

SAMSON, A. (Ed.). The Behavioral Economics Guide 2014 (with a foreword by George Loewenstein and Rory Sutherland), $1^{\text {a }}$ ed., 2014. Disponível em: $<$ http://www.behavioraleconomics.com $>$. Acesso em: 05 jul. 2015.

SBICCA, A. Heuristics in Consumer Decision. Ph. D. thesis (Economy) - Economia, Fundação Getúlio Vargas: São Paulo, 2010.

SBICCA, A. Heuristics in Study of Economic Decisions: Contributions by Herbert Simon, Daniel Kahneman and Amos Tversky. Estudos Econômicos, São Paulo, v.44, nº. 3, p.579603, jul./set. 2014.

SCHWARTZ, H. Herbert Simon and behavioral economics. Journal of Socio-Economics, v. 31, no 3, p. 181-189, dez. 2002.

SENT, E.-M. Behavioral Economics: How Psychology Made its (Limited) Way Back into Economics. History of Political Economy, v. 36, nº 4, p. 735-760, dez./mar. 2004.

SHILLER, R. Behavioral economics and institutional innovation. Southern Economic Journal, v. 72, no 2, p. 269-283, fev. 2005.

SIMON, H. Behavioral model of rational choice. Quarterly Journal of Economics, v. 69, $\mathrm{n}^{\mathrm{o}} 1$, p. 99-118, fev. 1955.

SIMON, H. Models of man: social and rational. New York: John Wiley \& Sons, 1957.

SIMON, H. Theories of decision-making in economics and behavioral science. American Economic Review, v. 49, n. 3, p. 253-283, jun. 1959.

SIMON, H. El Comportamiento Administrativo: Estudios de los procesos decisorios em la organizacion administrative. $2^{\text {a }}$ Edition. Madrid, Ed. Aguilar, 1964

SIMON, H. Rationality as Process and as Product of Thought. The American Economic Review, Vol. 68, No. 2, Papers and Proceedings of the Ninetieth Annual Meeting of the American Economic Association, p. 1-16, mai. 1978. 


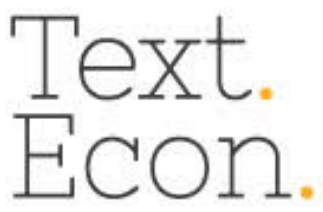

http://dx.doi.org/10.5007/2175-8085.2018v21n2p50

SIMON, H. An Empirically Based Microeconomics. Cambridge: Cambridge University Press, 1997.

SOMAN, D. The Last Mile: Creating Social and Economic Value from Behavioral Insights. Toronto: Rotman-UTP Publishing, 2015.

STRUMPEL, B; MORGAN, J; ZAHN, E. Human Behavior in Economic Affairs. San Francisco: Jessay-Bass Inc., 1972.

THALER, R. Toward a Positive Theory of Consumer Choice. Journal of Economic Behavior and Organization, v. 1, n 1, p. 39-60, mar. 1980.

THALER, R; SUNSTEIN, C. Nudge, Improving Decisions About Health, Wealth, and Happiness. New Haven: Yale University Press, 2008.

TOMER, J. What is behavioral economics? The Journal of Socio-Economics, vol 36, p. 463479, jan. 2007.

TVERSKY, A; KAHNEMAN, D. Judgment under Uncertainty: Heuristics and Biases. Science, v. 185, nº 4157, p. 1124-1131, set. 1974.

TVERSKY, A; KAHNEMAN, D. Judgment under uncertainty: Heuristics and biases. In Kahneman, D; Slovic, P; Tversky, A. Judgment under uncertainty: Heuristics and biases. Cambridge: Cambridge University Press, 1982. p. 3-22.

ZARRI, L. Behavioral economics has two 'souls': Do they both depart from economic rationality? The Journal of Socio-Economics, v. 39, nº 5, p. 562-567, out. 2010. 